DOI: $10.1515 /$ pof-2015-0002

VOLUME 7, ISSUE 1, 2015

ISSN: 2036-5438

\title{
Rights of Minors and Constitutional Politics in the German Länder. Legal Framework, Party Strategies, and Constitutional Amendments
}

by

Astrid Lorenz*

Perspectives on Federalism, Vol. 7, issue 1, 2015 


\section{Abstract}

The article analyses constitutional politics in the German Länder in the field of minors' rights. Since this issue seems a purely legal matter dealt with at the federal, European and international level, we should expect similar, almost identically shaped policies at the Länder level. However, the analysis brings considerable variations of constitutional activities in this field to the fore: time, frequency, and contents of respective initiatives vary significantly in the period from 1999 to 2014. These variations were due to different party strategies, diverging party platforms and majority constellations in the Länder. The analysis also shows that the public arguments brought forward in favour of constitutional amendments refer only weakly and randomly to legal provisions and processes at other levels. The political debate supporting extended children's rights rather refers to general observations, to the specific regional context, and constitutional provisions in other Länder. At least with regard to this issue, the multi-level system did not systematically impact on constitutional politics in the Länder. It rather can be understood as an opportunity structure providing parties with multiple realms in which they can pursue their goals. Thus the study shows that federal and regional party strategies are key factors in explaining policy diffusion in multilevel systems.

\section{Key-words}

Federalism, subnational constitutionalism, Germany, rights of the child, party politics 


\section{Introduction ${ }^{\mathrm{I}}$}

In the past decades, constitutional politics have gained increasing scholarly attention. This research was influenced by the neo-institutionalist paradigm. According to this approach, institutions empower actors and at the same time constrain their behaviour. Therefore, actors can be interested in changing them. In consequence, it is crucial to explore the influence of particular institutional contexts on the patterns of politics but also the reasons for changes to the constitutions (Lutz 1994; Lorenz 2005; Roberts 2008; Hayo and Voigt 2013; Robinson and Torvik 2008; Voigt 1997, 1999; Ticchi and Vindigni 2010; Vermeule 2001).

In times of globalisation, Europeanisation and decentralisation, a growing number of studies deal with constitutional mechanisms and rivalries in multi-level systems (Gerken 2007; Ginsburg and Posner 2010; Tarr 1998; Reutter and Lorenz 2012; Benz and Broschek 2013; Benz and Colino 2011; Behnke and Benz 2009). They analyse the emergence of a new supranational constitutional law at the European level, the diffusion of constitutional or policy ideas and contents across countries and compliance problems (Elkins and Ginsburg 2013; Weiler 2003; Wiener 2008). These studies have made important contributions to better understand the rationale of constitutional politics and have brought to the fore how political systems with different legal traditions were ruled with and by law. Yet, two crucial questions still remain open: How intensively do actors at the lower levels refer to rules and processes at other levels? And what matters more in multi-level frameworks - the rules or the parties interpreting the rules?

Many studies assume that the legal norms match reality on a sort of one-to-one-basis. Accordingly, processes at a subordinate level should be shaped by rules from above, i.e. a superior level. However, empirical studies on compliance or Europeanisation often indicate that the structure of the norm addressees, their beliefs and preferences influence the effect of institutions (Börzel and Risse 2012; Goetz and Meyer-Sahling 2008; Benz 2004). In fact, we know from comparative parliamentary and policy studies that the legislative output mirrors diverging preferences of leftist and conservative parties. But can this hold true in constitutional politics with its often higher majority hurdles? Institutionalist and veto player approaches (Tsebelis 2002) would deny this because provisions for qualified majorities give 
at least one oppositional party the power to veto any attempt for constitutional change which is not in line with its preferences. Because of this moderating institutional effect, differences in the government composition of lower level parliaments would not necessarily result in diverging constitutional outputs.

As a contribution to a better understanding of the causal mechanisms in multi-level systems, the present article analyses the patterns of constitutional politics concerning minors' rights ${ }^{\mathrm{II}}$ in Germany and its Länder. These cases are 'most likely cases' (Gerring 2007, Eckstein 1975, George and Bennett 2005) for a strong effect of rules at upper levels. At least this is what many scholars of German federalism suggest. It is used to speak about Germany as a 'unitary' federalism and a 'grand coalition state' in which many policy fields at the federal and state level are regulated by the two major parties, the Conservatives and the Social Democrats, in a rather homogenous way (Abromeit 1992; Hesse 1962; Scharpf et al. 1976; Schmidt 2007: 196 ff.; Helms 2007). This interpretation also refers to the state constitutions which are said to be overshadowed by the federal constitution (Cancik 2003; Stiens 1997; Braunschweig 1993). Such a legal determinism of the federal and other upper levels is against the idea of sub-constitutionalism as a kind of autonomy of subordinate states within a loose two-tiered legal framework.

In fact, in a multi-level polity, not all levels of constitutionalism need to address the same issues. In Germany, the federal constitution provides a catalogue of basic rights which, of course, apply to minors, as well. In addition, the Basic Law provides that the federal level is responsible for the foreign policy and the representation of national interests in the European Union. It thus decides on legal affiliations to international or supranational organisations and international agreements that might influence minors' rights in Germany. Hence, the rules and processes at superior levels should have strong effects on the constitutional handling of minors' rights in the Länder.

However, if international legal obligations affect Länder competencies, then the Länder must consent to them before ratification. They enjoy state quality and are entitled to pass laws in their own right. They can establish similar or more protective rights concerning minors in their Land and can create own state organisational rules, e.g. in the field of Land electoral law. In this way, they can function as laboratories for inventing and testing new constitutional norms (cf. Häberle 1993; Dombert 2012: 21). We know that Land parties' aims can differ from those of their federal party organisation (Lehmbruch 2000; 
Bräuninger and König 1999; Renzsch 2000). Similar to the well-known multi-level games at superior levels (Putnam 1988; Moravcsik 1997; Wolf 2000; Woll and Jacquot 2010), parties might be interested in influencing the national status quo by also playing such games at a subordinate level.

Accordingly, the German Länder are ideal cases to study the impacts of multi-level systems on subnational constitutional politics in the field of minors' rights. The study investigates which initiatives were made concerning the subject, which arguments and references were used by the political actors and how the legal framework and legal activities at the international, European, or federal level were referred to. Such an in-depth analysis makes it necessary to limit the period of investigation and the number of cases. Yet the chosen period of 15 years beginning in 1999 seems long enough to produce robust results. The study covers four states with maximal variation concerning government composition. Exploring two cases per group shall decrease the risk of misinterpretations. Table 1 shows that Bremen and Berlin were mostly run by SPD-led governments, while the CDU headed the governments in Saxony and Thuringia. ${ }^{\text {III }}$

Table 1: Party composition of federal and Land governments ${ }^{\text {a) }}$ between 1999 and 2013

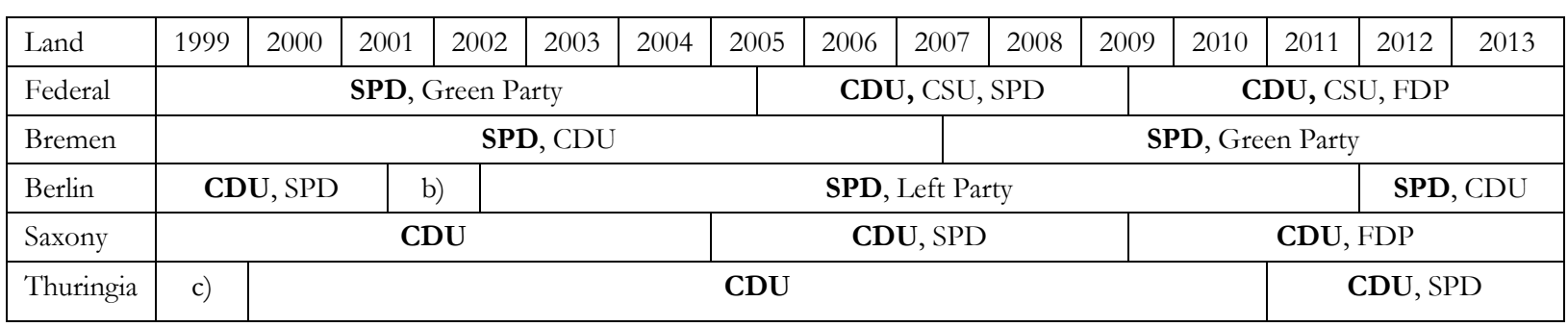

CDU = Christian Democratic Union of Germany, CSU = Christian Social Union of Bavaria, FDP $=$ Free Democratic Party, Green Party = Alliance $90 \&$ The Greens, SPD = Social Democratic Party,

a) Parties named first and printed in bold letters lead the government; they nominate the chancellor resp. the prime minister; b) between June 2001 and January 2002, the SPD and the Green Party set up a minority cabinet supported by the Left Party; c) a coalition of CDU, SPD was in power until September 1999.

In most other respects, the selected Länder share the same side conditions. In all states, constitutional amendments to the Land constitution need to be adopted by a two-thirds majority in parliament. In all states, the same parties (CDU and SPD) were able to prevent a constitutional amendment. All four states get huge fiscal transfers from the federal level and other Länder as almost all federal states do. Table 1 also shows that the period of investigation covers legislative terms in which the Land governments were formed by the 
same coalitions as at the federal level. That allows it to study a potential effect of symmetric or diverging party structures at federal and Land level.

The first part of the paper gives an overview of the legal setting concerning minors' rights at the federal, international, supranational, and Land level. Section two traces all processes (successful as well as failed ones) relevant for the constitutional handling of minors' rights in the four Länder. Section three provides a comparative analysis of time, frequency, contents and arguments of constitutional politics concerning the subject and uncovers remarkable variations. Obviously, constitutional politics on minors' rights differ significantly in the German Länder. At the same time, the study detects many vertical and horizontal linkages. ${ }^{\text {IV }}$ The conclusion summarises the findings and makes suggestions for further research.

\section{The Framework of Law and Legal Activities Concerning Minors' Rights}

The German Basic Law (BL) applies to minors in the same way as to anybody else. To respect and protect human dignity and free personal development is the duty of all state authorities (Art. 1 and 2 BL). Yet, there seems to be tension between the duty the state has to fulfil and the rights of the parents because according to article 6, child care and education are the parents' natural right as well as their obligation. The state has to "watch over them in the performance of this duty" (Art. 6 par. $1 \mathrm{BL}$ ). In the first decades of jurisdiction, these federal provisions were interpreted in such a way that children rather were understood as objects of parental and state action, not as subjects with own, individual rights. Moreover, parents enjoyed more rights concerning their children than any other social or public institution.

The Länder can neither circumvent nor abrogate these federal legal standards but they can provide for the same or more protective rights than the Basic Law in their realm of jurisdiction. At the beginning of the investigation period, all four Land constitutions made the protection of families, child care and education the natural right of the parents. ${ }^{\mathrm{V}}$ The states' provisions were, thus, similar to that of the German Basic Law. Additionally, the Saxon and the Thuringian constitutions which were adopted in 1992 and 1993, took up some specific formulations of the 1990 UN Convention on the Rights of the Child. Article 
9 of the Saxon constitution as well as Article 19 of the Thuringian constitution recognised the right of each child to a healthy mental and physical development and the special need to protect the youth against moral, mental, spiritual and physical threats. Moreover, the state has to provide preventive health care for children and young people and an infrastructure for child care. At the beginning of the investigation period, the voting age was fixed at 18 years old, although the Bremen constitution did not include this provision. It was laid down in ordinary law.

The UN Convention on the Rights of the Child (UNCRC) which had been a point of reference for the constitution-makers in Saxony and Thuringia, was signed by Germany in 1992 but with limitations. ${ }^{\text {VI }}$ The Convention covered a large array of aspects concerning children which partly affected core rules of national sovereignty or deviated from German national standards of protection. About 40 articles of the UNCRC comprised provisions concerning well-being, counter-discrimination measures, cultural rights, privacy, asylum, penal law and many other subjects. Other articles referred to the implementation of the provisions (United Nations 1990). The then incumbent federal government of CDU/CSU and FDP declared that the convention was not directly applicable within Germany and made several objections concerning custody, family and right of inheritance, judicial proceedings, the residence of foreign children in Germany, military service of children. These objections were stated in an attachment to the ratification law. In fact, the UN Convention "does not contain a provision expressly obligating its comprehensive incorporation or requiring it to be accorded any specific type of status in national law" (Detrick 1999: 27).

In this and the following legislative periods, the parliamentary parties of the socialist PDS, the Social Democrats and the Greens introduced separate initiatives to the federal Bundestag to improve and extend children's rights in the Basic Law. ${ }^{\text {VII }}$ In addition, the Socialists wanted to lower the voting age to 16 years old. The conservative-liberal majority rejected each of these initiatives and abstained from ratifying the European Convention on the Exercise of Children's Rights which was adopted in 1996 by the European Council. This convention aimed at establishing similar European provisions for the procedure of implementing the UN Convention on the Rights of the Child.

Although the Social Democrats formed a federal governmental coalition with the Greens in 1998, the majority constellation in the Bundesrat did not allow for federal 
constitutional changes since these must be passed by two-thirds majorities in the Bundestag and in the Bundesrat. The red-green government therefore focused on amending ordinary law concerning minors. Conflicts with Land governments provoked a further delay of ratifying the aforementioned European Council Convention in Germany until 2001. The conflicts with the Länder were also the reason why the red-green federal government had not formally withdrawn the objections to the UN Convention. However, it declared that the objections had only an informal status and were interpreted as no longer being in force. A 2001 bill of the Socialist PDS to include clauses in the Basic Law that children own legal rights and that their well-being and equal treatment is the main task of parents and the state again failed to be adopted.

In 2002, a Special Session on Children of the UN General Assembly consented on an outcome document entitled "A World Fit for Children". This was to encourage the member states to prepare national action plans concerning children's rights. Yet, several non-governmental organisations in Germany used the UN document to lobby for legal and practical improvements for minors. After years of coordination with various representatives of the federal level, the Länder, local authorities, non-governmental organisations, scientists and young people, the federal government adopted the "German National Action Plan 2005 to 2010". VIII This Action Plan included, among other issues, political measures to improve the political participation of minors which had been less in the focus of the federal political actors before. However, it again ignored proposals to amend the federal constitution.

Although the composition of the federal government changed after the 2005 elections, the action plan was realised by the new coalition of Social Democrats and Conservatives. It was during that period, too, that the European Union embraced the idea of promoting children's rights inside and outside Europe (Iusmen 2013: 1). However, the EU policymaking actions in this field lacked coherence and the EU competence to undertake them was contested. Moreover, the actions focused on concrete measures such as a hotline for missing children (Iusmen 2013: 1). Likewise the UN Convention on the Rights of the Child, no similar responses by the EU member states followed but the topic of children's rights remained to form part of the political agenda. In 2007, the oppositional Green Party as well as the Left Party introduced separate bills into the Bundestag to have children's rights included in the Basic Law. While the Greens' initiative was similar to a bill previously 
made by the Socialists, the latter now focused on strengthening the participatory rights of minors. Due to the Conservatives' stance on this issue, these initiatives were dead on arrival.

At that point some Länder became more active in this policy field. In cooperation with the parliamentary party of the SPD in the Bundestag, the Länder governed by Social Democrats wanted to have the Bundesrat take the lead in this matter. Since 2007, Land governments ruled by the SPD had tried several times to start the respective legislative process via the Bundesrat. Yet, the Land governments headed by the CDU or the CSU refused to start a Bundesrat initiative to include children's rights into the Basic Law. ${ }^{\text {IX }}$ However, the supporters of the idea were strengthened by the fact that in 2009, the European Union signed the Treaty of Lisbon which in Article 6 incorporated the Charter of Basic Rights of the European Union into the EU quasi-constitutional framework. Taking up ideas of the UN Convention, Article 24 of this charter defined particular rights of the child. According to this article, children shall have the necessary rights to sufficient protection and care. They may express their views freely which shall be taken into consideration on matters which affect them in accordance with their age and maturity and in all actions relating to children, whether taken by public authorities or private institutions. The child's best interests must be a primary consideration. ${ }^{\mathrm{X}}$

The continuing demands by the Bundestag and the Bundesrat as well as the political discourse stimulated by these demands and the EU context probably changed the perception of the Conservative party at least partly. In 2010, the conservative-liberal government withdrew their objections against the UN Convention on the Rights of the Child after Bundesrat and the Bundestag had consented. The opposition parties were busy in demanding that the federal government should also change the legal provisions concerning minor asylum seekers and do more for children in many aspects. In 2012, each party in opposition, i.e. the SPD, the Green and the Left Party, demanded - separately - to strengthen the role of minors as legal subjects by a constitutional amendment. In addition, the public policies were to give greater attention to the physical and mental well-being and development of children. All initiatives referred to the UN Convention. They differed with regard to the wording and the concrete policy measures. Additionally, Greens and Socialists re-introduced bills to lower the voting age. 


\section{Processes at the Länder Level}

How did these legal norms and processes at upper levels affect state constitutional politics the field of minors' rights? 'This section starts with observing parties' legislative behaviour in Bremen and Berlin that were both governed by SPD-led governments. It then proceeds with Thuringia and Saxony, two Länder with strong Christian parties. The analysis is mostly based on printed matters and plenary minutes retrieved from the four Land parliaments.

\subsection{Constitutional Politics and Minors' Rights in Länder Governed by SPD-led Coalitions}

In Bremen, the SPD headed two coalitions between 1999 and 2013. It coalised with the CDU until 2007 and with the Greens between 2007 and 2013. Under the first government composed of Social Democrats and Christian Democrats, the oppositional Greens demanded in 1999 to realise an electoral reform that also affected constitutional participatory rights of minors. Among others, the voting age should be lowered to 16 years old $^{\mathrm{XI}}$ to give minors more political influence. The Greens used several arguments to support their proposal: a recent decision of the Constitutional Court of North RhineWestphalia, research reports showing that young people are intellectually mature and able to make decisions, a 1996 expert commission of the German Bundestag which had supported the idea to lower the voting age, and a petition of a local school. The Christian Democrats refused the arguments. The Social Democrats expressed their general liking for the proposal but declared that this would not solve the youth policy problems. However, the Standing Constitution and Statute Committee of the Land Parliament in Bremen got the mandate, inter alia, to look further into the idea of lowering the voting age.

In 2001, the Bremen Parliament published a report about the simulation project "Youth in Parliament". On this occasion, the Greens demanded again to lower the voting age to 16 years old. All arguments in support of these demands referred to the youth in general or to the particular situation in Bremen. On this occasion, the Greens did not refer to any of the Bundestag initiatives for constitutionalising minors' rights. The governing factions CDU and SPD agreed that the participation of young people should be encouraged and asked the government to work out a concept for the promotion and 
participation of minors. The plenary discussions mentioned positive experiences in the nearby city of Hamburg and in Baden-Württemberg but the voting age reform was rarely mentioned. Instead, the speakers focused on other issues like right-wing extremism and local developments.

In 2002, in the context of the Special Session on Children of the UN General Assembly, the Green Party demanded to introduce children's rights into the Land constitution of Bremen. Representatives of the Green Party argued that the Länder were now obliged to implement the UN Convention on the Rights of the Child. The existing constitutional provisions on the right of education, equal treatment, and state protection from neglect were from the Greens' perspective insufficient in making the public aware of children's rights. Especially the independent individual development should get the status of a constitutional right. The Greens also mentioned that ten other Länder had already discussed introducing children's rights in their Land constitution. In North RhineWestphalia, all factions had even unanimously approved a respective modification of the constitution. Interestingly, they did not mention Rhineland-Palatinate where such rights had been adopted even earlier and with the support of the CDU, the SPD and the FDP.

Once again, the Social Democrats sympathized with this initiative but tried to postpone a decision to avoid endangering the incumbent coalition with the CDU. The SPD argued that an enlarged and intense discourse in Bremen on this proposal was necessary. Moreover, it found that the system of basic rights, as established in the Basic Law, could be damaged by particular state constitutional provisions concerning the rights of children. The Christian Democrats and the government stated that the Bremen constitution contained enough provisions for a legal protection of children's rights. The amendment to the constitution, as proposed by the Greens, would only replicate the recent modification of federal ordinary law concerning the rejection of violence in education at the Land level. Here we can observe a pattern that is true for all cases. Supporters of the status quo tend to refer to the federal legislative framework and argue that it must be followed by the respective Land.

During the legislative process, all societal actors that were officially invited to formulate their position on this topic, were in favour of including children's rights in the Land constitution. A synopsis proved that 7 out of 16 Land constitutions entailed child-related provisions while 4 contained provisions similar to Bremen and 5 contained neither 
children's rights nor youth protection clauses. The debates mirrored diverging perceptions of the legal framework and diverging party positions within and across the state. The actors referred to events at upper levels and horizontal impulses which fitted to their own political preferences and tried to use them as resources to place pressure on the governmental majority. In the end, the Social and Christian Democrats agreed in 2003 to a constitutional amendment. This policy change was due to the hearings, the comparison with other Länder, and the impact of the debate on the topic. It has to be noted that the Bremen Conservative Party took a different position than the Bundestag Conservatives faction.

In the following legislative term, the Bremen Greens re-introduced a motion to lower the voting age to 16 years old. It was based on the same arguments as in the previous initiatives concerning this issue. The discussion referred nearly exclusively to the Bremen urban context and to general arguments concerning young people's ability to make decisions. Only the Christian Democrats referred to North Rhine-Westphalia. Based on negative experiences with the election age of 16 in local elections, this Land had reincreased the voting age to 18 years old. The initiative of the Greens was rejected.

After the 2007 Bremen elections, the Social Democrats formed a coalition with the Greens. They established a parliamentary committee to draft a reform of political participation including lowering the voting age for local and possibly Land elections to 16 years old. The arguments included federal legal aspects which, however, were not predominant. They did not focus on minors' rights but more on other elements such as direct democracy. The committee considered legal changes in other German Länder as well. Finally, the SPD pointed out that German law contains various age limits that have been changed over time. Yet CDU and FDP refused any change to the voting age. They argued that the electoral law in Bremen should mirror federal law. Hence, it should prescribe that voters must possess German nationality and have the legal age of adulthood which is fixed at 18 years old. To both parties, deviating from federal regulations by establishing a voting age of 16 years old would cause a serious inconsistency in the legal system.

The governmental majority ignored the vetoes and used the fact that the voting age was ruled outside the constitution in ordinary law which could be altered by a simple majority. It lowered the voting age not only for local, but also for Land elections. This was justified with the peculiarity of Bremen as a city state where Land politics can hardly be separated from local politics. However, the veto of the Christian Democrats made it impossible to 
include these provisions into the constitution although the committee also had to check the possibility of constitutional changes.

Only in 2013 do we find an explicit linkage of the Bremen processes to the federal level. At that point, the Bremen parliamentary parties of the SPD and the Greens focused on changes at the federal level. With reference to the 1992 UN Convention on the Rights of the Child, they obliged Bremen to support a motion to the federal upper chamber to add children as legal subjects (not only objects) into article 6 of the German Basic Law or similar motions of other federal states. This initiative was nearly two years after the oppositional Social Democrats and Greens (as well as the Socialists) Bundestag factions had introduced a similar motion at the federal level. However, the motion failed to be passed by the Bundesrat.

In Berlin, the second Land with an SPD-led government between 1999 and 2013, the first legal initiative to change minor-related issues in the constitution was introduced in 2005. ${ }^{\mathrm{XII}}$ It referred to the local, not the state level. The voting age for the election of local authorities within the Land Berlin and local referenda was reduced from 18 to 16 years old. This constitutional amendment was initiated during a left-wing coalition composed of the SPD and the Left Party but it was introduced jointly with the Greens and the FDP. In Berlin, the Green Party had been trying since 1997 to lower the voting age to 14 years old. In order to support their bill, the initiators referred to general reflections about the participation of minors, to recent findings of research on this topic and to the good experience in other Länder with a comparable voting age. Federal ruling was only mentioned by Christian Democrats who rejected the amendment. They referred to the linkage between electoral right and the legal age in federal law and thus used quite similar arguments as their party colleagues in Bremen.

Shortly before the end of the legislative term, in 2006, all Berlin parliamentary parties introduced and adopted a constitutional amendment covering several subjects. It also included the provision that citizens aged 16 years old and older have the right to participate in a 'popular initiative'. Successful popular initiatives force the Land parliament to deal with a certain political issue. In this way, the constitutional amendment affected state-level politics, not only local affairs. Once again, the CDU in Berlin took a stance diverging from their Bremen sister party faction and the federal party organisation.

In 2007, the oppositional Green Party in parliament introduced a motion to alter article 
13 of the Berlin constitution. This motion was probably triggered by developments at the federal level. This motion addressed several issues: each child was to be respected as an independent individual, it was to enjoy special protection by the state and the society; it should have the chance to develop individually, the right to non-violent education, to be heard on issues which affect them and the right to schooling. Young people should be guaranteed vocational training and have the right to exercise the profession. The Greens argued that Germany in general and Berlin in particular performed poorly with regard to children's protection compared to other countries and Länder. According to the Green Party, children were not sufficiently respected as independent personalities. On the contrary, children were objects of violence and not taken care of. In addition, they lacked sufficient opportunities for development and participation. The proposed constitutional amendment was to improve this performance by obliging the state and society to assist children. There was no special reference to other levels.

At the same time, the Green Party as well as the SPD and the Left Party introduced many other inquiries and motions concerning the social situation and participatory rights of children and young people. The plenary discussions on the proposed constitutional amendments covered all these initiatives. In fact, the MPs addressed general problems of children and their societal status in their talks rather than the bill proposing a constitutional amendment. Their arguments made little reference to other political systems or levels. Only the government mentioned the federal level. Being a supporter of the status quo, it stated that the constitutional amendment should be postponed until the federal level has made a respective decision on this topic.

Although the motion was not adopted, two years later, in 2009, an inter-factional initiative followed. Now the governmental parties, i.e. the SPD and the Left Party, introduced a bill together with the Christian Democrats and the Green Party. According to that bill, article 13 of the Berlin constitution should guarantee each child the right to personal development and non-violent education. State and society were to protect children against violence, neglect and abuse. The state community should respect, protect and promote the rights of each child and provide living conditions fit for children. The initiative was based on general arguments concerning the rights of children and the role of the state and parents in the spirit of the UN Convention on the Rights of the Child. In the plenary debate, the Greens stressed their will to introduce a provision about children's 
rights also in the Basic Law and to lower the voting age. The CDU stated that the amendment was a wrong way but they supported it nevertheless because of the high public pressure to do so. Thus, they changed their position as their Bremen party colleagues had done in 2003. Like the Liberal Democrats, they dealt with the effects of the amendment on the federal legal system. Yet unlike the FDP which rejected the constitutional amendment, they consented to it.

In the same year, 2009, the Green Party of Berlin introduced a constitutional amendment bill to lower the voting age for Land elections to 16 years old. The Greens built on positive experiences made at local elections in Berlin. This seemed to be a perfect argument to realise the next reform. Another argument was the inconsistency that 16 year olds were entitled to sign Land people's initiatives, but not vote in Land level referenda. They also referred to scientific studies concerning young people and to legal norms, reforms and discussions in other Länder which supported their goal. Another argument was that one of the most important policy competencies of the Länder is education. Evidently, young people are foremost affected by respective-decisions. Young people should therefore be entitled to participate in Land elections at an earlier age to have a say on these issues.

All parties supported their view, once again, by referencing general reflections about young people. Some arguments were similar to those used in Bremen but many others diverged. Additional arguments were shaped by the particular Berlin context. The governing SPD, for instance, hesitated to adopt the constitutional amendment before the upcoming Land elections. It wanted to include the proposal into their election programme to mobilise social acceptance and legitimacy in the elections. Although the committee set up a hearing with experts who all supported the idea of reducing the voting age, the SPD's refusal of the idea let the bill fail in parliament.

The 2011 elections in Berlin led to a new coalition composed of the SPD and the CDU. One year later, the oppositional Green and Left Party jointly reintroduced the 2009 Greens bill to amend the constitution. The arguments remained the same. They mentioned earlier maturity, particular affectedness of young people by Land legislation, good performance in other German Länder, the need to take young people seriously, the interest in revitalising the democratic culture and others. On the same day, the new 'Pirates' Party faction introduced a bill to amend the constitution which provided for a lower voting age 
of just seven years old and the eligibility to 16 years old. This can be understood as a matter of party competition among the opposition. The Pirates' arguments referred only to general ideas concerning participation and children.

The Berlin SPD parliamentary group held an inconsistent position on this issue. It found that lowering the voting age in other Länder had not succeeded because the turnout of voters of 16 and 17 years old there was below average. The SPD concluded that it would not be enough to simply grant adolescents the right to vote. Such a privilege was to be combined with responsibilities to secure reciprocity between state and citizens. However, this linkage to federal law was not explicitly mentioned. The Greens referred to the fact that the SPD of Bremen had supported the idea. The Christian Democrats wanted to have the effects of a lower voting age in local elections better evaluated. Only then would it be possible to discuss the issue, once again. In the end, the bills were voted down.

To sum up the findings: In Berlin, the parties rather considered Bremen developments than impulses from upper levels. The UN Convention was selectively referred to and did not inspire the arguments decisively. Hence, horizontal impulses impacted more on constitutional politics in Berlin than vertical ones. Unlike Bremen, the parties in Berlin did not believe that different voting ages in one federal state are a problem. The federal level was important for the argument that the voting age should be consistent with the age of criminal responsibility which is determined at the federal level and fixed at the age of 18. However, this linkage between federal and Land law was called into question by others. The power constellation as well as specific Berlin-related concerns dominated the process. Therefore, the constitutional output differed at the end of the investigation period from the status in Bremen.

\subsection{Constitutional Politics and Minors' Rights in Länder with CDU-led}

\section{Governments}

In Saxony and Thuringia, the rights of children and young people were of less legislative concern for the parliamentary parties than in Bremen or Berlin. Furthermore, both Länder were latecomers in this respect. This may partly be due to the fact that both constitutions were put into effect in the early nineties and already contained certain rights of the child. Nonetheless, during the last years, the topic has gained more attention among the parties in opposition. In addition, there is some evidence about linkages between 
parliamentary parties in the Bundestag and the parliaments of Saxony and Thuringia. It seems that the Socialist and Greens federal party factions inspired the Land factions to engage in constitutional initiatives at their respective level as well as for initiatives aiming to change the federal constitutional framework.

In Saxony, the parliamentary party of the socialist PDS (later The Left Party) was the first one which addressed minors' rights. In 2002, it built on a recent initiative of the PDS Bundestag faction which was rejected. ${ }^{\mathrm{XIII}}$ Its aim was to include children's rights in the Basic Law. The Saxon parliamentary party now demanded that the Land parliament obliged the Land government to engage in the Bundesrat for more protective provisions concerning children's rights in the Basic Law. The role of children as legal subjects, not just as objects of laws, should be strengthened. Like in the other cases, we find here a reference to the UN Convention on the Rights of the Child and to Land constitutions that comprised children's rights. But the proposal also referred to rulings of the Federal Constitutional Court. It did not mention the fact that such Court's decisions had the status of federal quasi-constitutional law.

In 2007, the same party demanded to lower the voting age for local elections and referendums to 16 years old and thus followed the discourses described for Bremen and Berlin. But there, these initiatives had been introduced by the Green Party. The Saxon PDS argued that in other federal states a lower voting age worked well. In both motions, a vertical and horizontal impulse was present. The event of the UN Convention was used in the context of the UN Special session on children as an argument chip which however did not decisively shape the debate. The party programme influenced which parts of the UN Convention were referred to.

In 2008 - later than in the other cases of the sample -, the parliamentary party of the Greens in Saxony introduced a draft bill aiming at improving the participation of minors. This bill wanted to decrease the voting age for local elections to 16 and to entitle young people to participate in local planning processes. In addition, it included provisions to implement the right to childcare services. It again referred to the UN Convention on the Rights of the Child. Neither MPs of the Green Party nor from any other parliamentary group made reference to other federal states or the Bund level where the topic had been discussed, for instance, in the Bundesrat.

In the following legislative period, the Green Party renewed its initiative. Now, it 
comprised two possible constitutional amendments. The first one aimed at lowering the voting age in local and Land elections to 16 . The eligibility should remain at 18 years old. In order to support this proposal, the Greens argued, inter alia, that this would not contradict the Basic Law and referred to a decision made by the Administrative Court of Hanover (Lower Saxony). With the second motion the Green Party reintroduced the bill on extended participatory rights of young people and for service points assisting in realising these rights with reference to the UN Convention on the Rights of the Child. Here again, we see a loose, instrumental reference to upper-level rulings and a stronger horizontal reference to other Land rulings or jurisdictions to strengthen the own policy position.

The Saxon government kept arguing that the existing constitutional provisions were sufficient for the protection of children's rights. In consequence, the ruling parties in parliament rejected the motion to lower the voting age outright. They even refused to discuss the sense of such a reduction. Instead, they argued that the Land provided sufficient opportunities for young people to participate as well as assistance.

In Thuringia, as in Saxony, constitutional amendments were only demanded by the oppositional parliamentary parties. ${ }^{X I V}$ The opposition mainly referred to other Länder whose constitutional developments conformed to their demands. Only in 2008 did the issue get a constitutional status for the first time when the Left Party demanded to include children's rights into the Basic Law. This motion was linked to the described processes at the federal level around some rejected initiatives concerning children's rights. The Socialist Party demanded that the Thuringian government should give reasons for its refusal to a respective motion in the Bundesrat and should work towards the inclusion of such rights at the federal level. As a reaction, the CDU parliamentary party asked the government to report on its commitment regarding child and youth rights at the federal and Land level and to report on the status of child protection in the constitutions of the German Länder.

In 2012 and 2013 - much later than in the other cases and only in the form of small enquiries to the government - the oppositional Left and Green Party put the participation of children and young people back on the agenda. They referred to the UN Convention on the Rights of the Child and criticised that Thuringia had no ordinary law implementing the constitutional right to participate. In its answer, the government listed many concrete forms of participation for young people in Thuringia which were realised irrespectively of the absence of a particular law on youth participation. 
Like in Saxony, the Green and the Left Party aimed at lowering the voting age to 16. The Green Party started the process by introducing this request in 2010 but it was limited to local elections and did not comprise a constitutional amendment. The socialist Left Party introduced a similar motion in 2013 and complemented it with a bill to change the constitution to allow for a lower voting age in both local and Land elections.

The arguments in support of these proposals mirrored the former ones. They mainly referred to participation in Thuringia and to general social and value changes. Two arguments were crucial in this debate. On the one hand, it was argued that outdated electoral principles caused low political participation. On the other hand, young people were regarded as being more reasonable today and with greater insights at an earlier stage of life. Nowadays, adolescents grow up in an information and media society which creates the precondition to take over responsibility in democratic processes. The supporters, among them the Liberal Democrats, referred to developments in other Länder which had changed their laws accordingly. The Green Party referred to Austria and quoted the President of the Constitutional Court of Germany who saw a strong need to modernise electoral laws.

However, the governing party CDU rejected the initiatives referring to (federal) Criminal Law which is based on the perception of a gradual maturation process of people. According to this concept, people up to 21 years old are perceived to lack consciousness for the consequences of their action. Its coalition partner, the Social Democrats, joined in on this position to avoid endangering the coalition. Once again, the international and federal level was addressed selectively and with concurrent interpretations depending on the point of view to be supported in the debate.

\section{Comparing the Cases}

The comparative study of the cases shows that the parties at the subnational level referred to international, European, or federal norms concerning minors rather randomly. What is more, these references and interpretations of the legal framework were evidently inspired by their respective party position. Based on the analysis, we see two distinct ideological profiles (table 2) that can be linked to two different theoretical understandings of constitutions: The change-oriented position, represented by parties left-of-the-centre, 
normally takes the initiative, strives for encompassing regulations, is inclined to change a constitution fairly frequently and ascribes it a high educative value. The status-quo-oriented position, represented by the CDU and the FDP, seeks to change a constitution as little and as rarely as possible and only at a point of time when the constitutional norms are already accepted by the broad society. These programmatic positions were predominant in the discussions.

Table 2: Types of party positions concerning constitutional politics

\begin{tabular}{|cc|c|c|}
\hline $\begin{array}{c}\text { Aim } \\
\text { constitution }\end{array}$ & Of & $\begin{array}{c}\text { Change-oriented } \\
\text { Changing societal views } \\
\text { according to the normative good } \\
\text { Content } \\
\text { initiatives }\end{array}$ & $\begin{array}{c}\text { Mirroring } \\
\text { majority's views }\end{array}$ \\
\hline $\begin{array}{c}\text { Frequency } \\
\text { initiatives }\end{array}$ & Encompassing & Core rights \\
\hline
\end{tabular}

However, a second finding seems even more important. Although the same major parties functioned as partisan veto players for constitutional amendments in all four cases, the parties' level of activities and their success rate varied considerably across the cases. Accordingly, the Länder show remarkable variation in the constitutional handling of minors' rights. Obviously, the party composition of the Land government explains this variation. The mechanisms behind these effects of party constellation are shown in the following.

The effect of the parties materialises in a varying selectivity of issues and in varying interpretations of the legal framework. As a rule, the Länder covered only some of the issues included in the UN Convention on the Rights of the Child regardless of the fact that this Convention was often referred to. All initiatives dealt either with the formalisation of children's rights according to article 12 of the UN convention or with a lower voting age, i.e. with issues that were ideologically close to the SPD, Green and Left Party. No other children-related subjects of constitutional change were proposed during the 15 years under 
investigation. Moreover, the Charter of Basic Rights of the European Union or other legal documents were completely neglected.

Table 3: Failed and adopted constitutional initiatives concerning minors' rights

\begin{tabular}{|c|c|c|c|c|c|c|}
\hline Year & $\begin{array}{l}\text { Federal } \\
\text { government }\end{array}$ & Land & $\begin{array}{l}\text { Land } \\
\text { government. }\end{array}$ & Initiator & Subject & Status \\
\hline 1999 & & Bremen & SPD, CDU & Green Party & voting age & Failed \\
\hline 2002 & Green party & Saxony & $\mathrm{CDU}$ & SPD & rights of child & Failed \\
\hline 2003 & & Bremen & SPD, CDU & Green Party & rights of child & Adopted \\
\hline 2006 & \multirow{5}{*}{$\begin{array}{l}\text { CDU, } \\
\text { CSU, } \\
\text { SPD }\end{array}$} & Bremen & SPD, CDU & Green Party & voting age & Failed \\
\hline 2006 & & Berlin & SPD, Soc & $\begin{array}{l}\text { SPD, CDU, Left Party, } \\
\text { Green Party, FDP }\end{array}$ & voting age & Adopted \\
\hline 2007 & & Berlin & SPD, Soc & Green Party & rights of child & Failed \\
\hline 2009 & & Saxony & CDU, Lib & Green Party & voting age, rights of child & Failed \\
\hline 2009 & & Bremen & $\mathrm{SPD}, \mathrm{Gr}$ & SPD, Green Party & voting age & $\begin{array}{l}\text { Ordinary } \\
\text { law }\end{array}$ \\
\hline 2009 & \multirow{4}{*}{$\begin{array}{l}\text { CDU, } \\
\text { CSU, } \\
\text { FDP }\end{array}$} & Berlin & SPD, Soc & Green Party & voting age & Failed \\
\hline 2009 & & Berlin & SPD, Soc & $\begin{array}{l}\text { SPD, Left Party, CDU, } \\
\text { Green Party }\end{array}$ & rights of child & Adopted \\
\hline 2010 & & Thuringia & CDU, SPD & Green Party & voting age & Failed \\
\hline 2012 & & Berlin & SPD, CDU & $\begin{array}{l}\text { Green Party, Left } \\
\text { Party }\end{array}$ & voting age & Failed \\
\hline
\end{tabular}

Source of data: Bundestag and Land parliaments; my compilation.

In all cases, both issues - children's rights and voting age - were discussed nearly separately from each other although both concern the rights of the same addressees and are linked to the same UN charter which aims at strengthening the well-being and participation of young people. Only two of the 20 initiatives which were covered by the sample included both (Table 3). This separation is also observable for the other German Länder. It follows the traditional German judicial separation of basic and social rights on the one hand and state organisational rules on the other that also guided the judicial party politics.

The party families' interpretations of the legal framework were quite consistent across the Länder. While all parties referred to processes and rules in other Länder, at the federal or international level, their interpretations varied concerning the institutional freedoms and 
obligations that were set by the upper levels. In general, the Conservatives found children's rights already effectively protected, a voting age of 18 years old sufficient and participatory rights logically tied to the age of legal adulthood. Conservatives and Liberals argued that Land constitutional changes would only damage (in the case of the voting age) or replicate (in the case of children's rights) the existing federal constitutional law. The supporters of changes argued that the Länder had to implement the UN charter of rights by constitutional changes and they referred to other Länder or countries where the intended changes had been realised. However, the Social Democrats, the Green Party and the Socialists supported different models of constitutional changes.

Concerning voting age, the arguments of the parties were less coherent across the states and levels than concerning children's rights. The Green Party, for instance, introduced varying proposals for a lower voting age and better participation of minors. The position of the Liberals also differed. But the party rationale is apparent inside the states. The parties introduced most of their initiatives separately irrespectively of partly overlapping preferences. Obviously, establishing an own profile was more important to them than cooperating.

The mentioned effect of the government's party composition materialised in a varying frequency and a varying success rate of constitutional initiatives concerning minors' rights in each group of cases. Table 2 indicates that there were far more initiatives in those Länder whose governments were led by the Social Democrats. In Bremen, we found 6 initiatives, in Berlin 7, while in Saxony there were only 4 initiatives and in Thuringia 3. The starting points of setting children's rights and the voting age on the agenda also varied with the earliest initiatives in Bremen and Berlin whereas in Saxony and Thuringia which were governed by Conservative Parties, the topic was later and more seldom on the political agenda (except one outlier initiative in 2002).

The varying starting point and frequency of constitutional activism is highly interesting since we generally find the same initiators in all four Länder. The Green Party submitted 15 of 20 bills dealing with the rights of children and young people, the Left Party (formerly PDS) eight initiatives. One initiative came from the 'Pirates'. However, it seems that the party organisations focused their energy on Länder with a higher chance of realising their aim. Pro-change oppositional parties were much more pro-active under government coalitions that included the left-centrist SPD than in other circumstances. With only one 
exception, joint initiatives of the Greens and the Socialists or other parties were only introduced when at least one of the initiators was part of a government coalition. These joint initiatives were results of compromises between the parties. It seems that a realistic prospect for adopting an initiative is the only reason for parties to introduce an initiative with others and not alone.

While the Socialists and the Greens were most active in initiating changes, all constitutional amendments were only successful when they got support by the Social Democrats. In the Länder with SPD-led governments, half of the initiatives were approved. As Table 3 shows, the constitutional amendments were adopted under SPD-led governmental coalitions with the Christian Democrats (Bremen) and with the socialist PDS or its successor The Left Party (Berlin).

Interestingly, the Christian Democrats changed their position concerning explicit constitutional children's rights in both Bremen and Berlin and argued that public pressure had forced them to do so. That resulted in three constitutional amendments in Berlin (two concerning voting or referendum age, one concerning explicit Land constitutional rights of the child) and one constitutional amendment in Bremen where another, quasiconstitutional amendment was realised by an amendment of ordinary law. In the federal states which did not amend their constitutions, the Christian Democrats were the main governing party. Here, they were able to prevent longer parliamentary discussions of the topic. Accordingly, we cannot see whether they changed their view on the issue but we can suspect that due to the absence of frequent public discussions, there is no need for them to legitimise the own position and to think it through.

As a result of these mechanisms, the contents of the constitutional amendments vary, too. The constitutional provisions in all Länder under investigation include rights of all citizens in general and of parents in particular as well as measures for the physical wellbeing of children. However, the Länder governed by Social Democrats adopted more encompassing provisions. They wanted children to have a constitutional right to develop their personalities, to be raised without violence; in addition children should enjoy a special protection of the community against violence, neglect, and exploitation. In this way, individual rights of minors were highlighted and constitutionally circumscribed. Moreover, they obliged the state to respect, protect, and promote the rights of children as individual personalities and to ensure that the living conditions are suitable for children. It was not 
fixed how the suitability for children would be proven but at least the lower voting and referendum age was a way to provide some of the younger people with procedural rights to communicate their will to political representatives and the public administration.

Obviously, the varying constitutional treatment of minors' rights was also influenced by horizontal and vertical linkages between the party organisations. The pattern of partisan activities seems to be quite strategic. Some time after the pro-change initiatives had failed at the federal level because of the CDU's veto, similar initiatives were introduced in the more prospective Länder and after their adoption, initiators in the less prospective Länder became active and referred, inter alia, to these examples to support their proposals. In the meantime, the party factions at the federal level use Land constitutional reforms to support their own reform proposals at the federal level.

Interestingly, these linkages are rarely made transparent. When we interviewed constitutional experts of the Land parties, many of them stated that constitutional politics is mainly influenced by the particular regional settings and not a product of federal developments. Indeed, the concrete decision processes are influenced by the particular majority constellation in a Land but the diffusion of ideas and the inner-federal implications of the decisions are influenced by federal party structures. Citizens - and maybe even the negotiation partners at the Land level - are unable to understand these inner-federal constitutional dynamics when the Land party actors do not refer to activities of their sister party organisations in other Länder or at the federal level but mainly to those legislative outputs which are suitable to their aims and to regional affairs.

Even if this pattern of activity was not strategically coordinated by the federal party as a kind of multi-level game but simply arose from individual decisions based on the same political preferences of federal and Land party organisations and their embeddedness in a homogenous party discourse, it shows that the effect of institutions is strongly influenced by the preferences and strategies of exactly those parties whose action shall be bound by the rules. That makes the functioning of rules and norms ambiguous.

\section{Conclusion}

The article shows that in the field of constitutional rights of minors, the multi-level system composed by international, EU and German law is a dynamic and flexible structure 
with a varying impact on sub-national constitutional politics. That puts the notion of the 'unitary' German federalism in perspective. The same legal context was interpreted in different ways across Länder and party lines. Impulses to act did not come from the legal framework itself but from certain actors who found it favourable in the context of their party programme to refer to it. The party preferences also resulted in a high selectivity of constitutional issues that were put on the agenda. References to processes and rules in other Länder, at the federal or international level were used as instruments to support or reject constitutional initiatives. Insofar the multi-level system is a sort of "opportunity structure" providing the actors with multiple political realms in which they can pursue their goals. In addition, the multi-level system establishes communicative channels through which ideas and policies travel more easily.

Obviously, the federal and Land organisations of the parties stayed in contact and so the impulses and arguments passed the levels and state borders. Therefore, the constitutional issues concerning children's rights were put on the parliamentary agenda in all federal states. But the government structure influenced the level of activism and the constitutional output that differed across the Länder. The most pro-active parties were the oppositional Green and the Left Party. Their earliest and most activities took place in Länder governed by Social Democrats because the overlapping of preferences made an adoption of the initiatives more promising. While two constitutions were amended under SPD-led coalitions, no constitution was altered under a government led by the Christian Democrats.

Accordingly, the contents of the constitutions concerning minors vary in the observed German Länder. The superior levels set basic legal norms but state-level parties used their own shaping power concerning social and participatory rights. In SPD-led states, the voting age was lowered and children obtained an explicit constitutional right to develop their personalities, to be raised without violence, and to the special protection of the community against violence, neglect, and exploitation. Additionally, the state was obliged to respect, protect, and promote the rights of children. In the CDU-led states, the right to vote in elections or referendums remained limited to citizens aged 18 and above and the constitutional protection of children remained primarily a matter of the parents and state action that focused on their physical well-being. 
UNICEF emphasises today that the UN Convention on the Rights of the Child "changed the way children are viewed and treated - i.e., as human beings with a distinct set of rights instead of as passive objects of care and charity" (UNICEF 2014). The article shows that it overestimates its effect. In Germany, only article 12 of the Convention received special attention. The selection was clearly influenced by the particular policy preferences of the parties. Such a selective reception is less possible for the constitutional rules in the German Basic Law which must be implemented, but some parties engaged in creating additional, more protective norms at the Land level. This variation of constitutional protection for several societal groups questions the binding effect of institutions.

In sum, those perceiving and interpreting the rules seem to be more influential in the interplay between law and politics. At least they take a selective use of rules and create legal provisions according to their preferences and power constellation. But further research is needed concerning the question as to why the level of constitutional activism by Land factions of the same parties was so much lower in cases with conservative governments although this constellation would have provided a good opportunity for the opposition to get public attention. It is also still unclear how the federal and Land parties form their constitutional preferences. Finally and more generally, it remains open as to why the actors on the one hand take legal provisions seriously as an instrument and on the other hand perceive them and comply with them so selectively.

\footnotetext{
* The author is a Professor of Political Science at the Department of Political Science (University Leipzig).

I The research is funded by the German Research Council (grant no. GZ: LO 1424/3-1; AOBJ: 604048).

II It is typical for the German discussion to differentiate between minors as children and adolescents or juveniles (between 16 and 18 years old).

III Until now, other parties have not yet been the major party during a whole legislative term.

IV Due to limited space, only the most important sources are mentioned. Further information on the debates can be found at the websites of the four Land parliaments, i.e. https://www.bremischebuergerschaft.de/index.php?id=3, $\quad$ http://www.parlament-berlin.de/de/Dokumente, http://www.landtag.sachsen.de/de/parlamentsdokumente/, http://www.parldok.thueringen.de/parldok. $\mathrm{v}$ Art. 12 of the 1995 Berlin constitution, Art. 22 of the Saxon constitution, Art. 17 and 18 of the Thuringian constitution, Art. 23 of the Bremen constitution. The respective Land constitutions can be retrieved from http://bremen.beck.de/default.aspx?bcid=Y-100-G-brverf-name-inh, $\quad$ http://www.berlin.de/rbmskzl/ regierender-buergermeister/verfassung/, http:/ www. revosax.sachsen.de/Details.do?sid=4341016086322, http://www.thueringer-landtag.de/landtag/gremien-und-

rechtsgrundlagen/rechtsgrundlagen/landesverfassung/.

VI The UN General Assembly adopted the Convention in 1989; it entered into force on 2 September 1990.

VII For the analysis of the developments at the federal level, the following printed matters by Deutscher Bundestag were used: 12/6323; 13/2574; 14/5438; 15/1819; 14/7818; 15/4970; 16/817; 16/5005; 16/7110; 17/6920; 17/7187; 17/7644.
} 
VIII It set the following policy priorities: Equal opportunities through education, a non-violent upbringing, the promotion of health and healthy environmental conditions, participation of children and youths, development of an adequate standard of living for children, and international commitments for improving children's rights.

IX See these plenary minutes by the Bundesrat. 840. Sitzung - 20. Dezember 2007; 846. Sitzung - 4. Juli 2008; 856. Sitzung - 6. März 2009; 885. Sitzung - 8. Juli 2011; 890. Sitzung - 25. November 2011; 891. Sitzung 16. Dezember 2011, available at http://www.bundesrat.de/DE/service/archiv/pl-protokoll-archiv/plprotokoll-archiv-node.html.

$\mathrm{x}$ Another clause is that every child shall have the right to maintain a personal relationship and direct contact with both his or her parents on a regular basis, unless that is contrary to his or her interests.

$\mathrm{XI}$ The analysis is based on printed matters and plenary minutes of the Bremische Bürgerschaft. For the most important arguments see the following printed matters: Drs. 15/11, 15/37, 15/46, 15/710, 15/717, 15/1150, 15/1340, 15/1411, 16/951, 17/52;17/53,17/88, 17/934, 17/934; 18/803, we also retrieved information from the following minutes: $15 / 3,15 / 61 ; 15 / 72,15 / 75,15 / 76,16 / 58,17 / 8,18 / 40$.

XII The analysis is based on printed matters and plenary minutes of Abgeordnetenhaus von Berlin. For the most important arguments see the following printed matters: Drs. 15/4068; 15/5038; 16/0567; 16/2805; 16/2799; $17 / 0111 ; 17 / 0106$. We also retrieved information from the following minutes: 15/70, 15/73; 16/13; 16/55; $16 / 60 ; 16 / 55 ; 16 / 82 ; 17 / 7$.

XIII The analysis is based on printed matters and plenary minutes of Sächsischer Landtag. For the most important arguments see the following printed matters: Drs. 3/6983; 4/8223; 4/11143; 4/12533; 5/7651; 5/5127; 5/13867. Also see the minutes 4/110, and 4/138.

xIV See the following printed matters by Thüringer Landtag: 4/4460; KA 5/2482; KA 5/3351; 5/6771;

$5 / 478 ; 5 / 6075 ; 5 / 6121$. Also see the plenary minutes $5 / 12 ; 5 / 33 ; 5 / 118 ; 5 / 121$.

\section{References}

- $\quad$ Abromeit Heidrun, 1992, Der verkappte Einheitsstaat, Leske und Budrich, Opladen.

- Basic Law for the Federal Republic of Germany, available at http://www.bundestag.de/htdocs e/documents/legal.

- $\quad$ Behnke Nathalie and Benz Arthur (eds), 2009, Federalism and Constitutional Change, special issue of Publius. The Journal of Federalism, XXXIX(2).

- $\quad$ Benz Arthur, 2004, 'Path-Dependent Institutions and Strategic Veto Players - National Parliaments in the European Union', West European Politics, XXIX(5): 875-900.

- Benz Arthur and Broschek Jörg, 2013, Federal Dynamics: Continuity, Change, and the Varieties of Federalism, Oxford University Press, Oxford.

- Benz Arthur and Colino César, (eds), 2011, Federalism and Constitutional Change. Theoretical and Comparative Perspectives, special issue of Regional and Federal Studies, XXI(4-5).

- Börzel Tanja A. and Risse Thomas, 2012, From Europeanisation to Diffusion, special issue of West European Politics, XXXV(1).

- Bräuninger Thomas and König Thomas, 1999, 'The Checks and Balances of Party Federalism', European Journal of Political Research, XXXVI(2): 207-234.

- Braunschweig Stefan von, 1993, Verfassungsentwicklung in den westlichen Ländern, Centaurus, Pfaffenweiler.

- Cancik Pascale, 2003, 'Die Verfassungsentwicklung in Hessen', Jabrbuch des öffentlichen Rechts (Neue Folge), LI: 271-300.

- Charter of Fundamental Rights of the European Union (2000/C 364/01). Official Journal of the European Communities 18.12.2000.

- $\quad$ Detrick Sharon A., 1999, Commentary on the United Nations Convention on the Rights of the Child, Kluwer, The Hague.

- Dombert Matthias, 2012, '\$27 Landesverfassungen und Landesverfassungsgerichte in ihrer Bedeutung für den Föderalismus', in Härtel Ines (ed), Handbuch Föderalismus - Föderalismus als demokratische Rechtsordnung und Rechtskultur in Deutschland, Europa und der Welt, vol. II, Springer, Heidelberg, 19-37.

- $\quad$ Eckstein Harry, 1975, 'Case studies and theory in political science', in Greenstein Fred and Polsby 
Nelson (eds), Handbook of Political Science, vol. 7, Addison-Wesley, Reading, MA, 79-138.

- $\quad$ Elkins Zachary and Ginsburg Tom, 2011, 'Comparative Constitutions Project. Database', available at http://comparativeconstitutionsproject.org/ (accessed: 25 Aug. 2013).

- George Alexander L. and Bennett Andrew, 2005, Case studies and theory development in the social sciences, MIT Press, Cambridge, MA.

- Gerken Heather K., 2007, 'The Hydraulics of Constitutional Reform: A Skeptical Response to Our Undemocratic Constitution', in Drake Law Review, LV(4): 925-951.

- $\quad$ Gerring John, 2007, Case study research, Cambridge University Press, New York.

- Ginsburg Tom and Posner Eric A., 2010, 'Subconstitutionalism', Stanford Law Review, LXII(6): 1583-

1628.

- Goetz Klaus H. and Meyer-Sahling Jan-Hinrik, 2008, 'The Europeanisation of national political systems: Parliaments and executives', Living Reviews in European Governance, III(2): 4-22.

- Häberle Peter, 1993, 'Die Verfassungsbewegung in den fünf neuen Bundesländern', Jahrbuch des öffentlichen Rechts der Gegenwart (Neue Folge), XLI: 69-92.

- Hayo Bernd and Voigt Stefan, 2013, 'Endogenous constitutions. Politics and politicians matter, economic outcomes don't', Journal of Economic Behavior \& Organization, LXXXVIII: 47-61.

- Helms Ludger, 2007, 'Föderalismus und Bundesstaatlichkeit in Deutschland', in Europäisches Zentrum für Föderalismus-Forschung, (ed), Jahrbuch des Föderalismus 2006, Nomos, Baden-Baden, 115-135.

- $\quad$ Hesse Konrad, 1962, Der unitarische Bundesstaat, Müller, Karlsruhe.

- Iusmen Ingi, 2013, 'When Good Intentions Go Astray: Policy Framing processes and the Europeanization of Children's Rights', The British Journal of Politics and International Relations, DOI: 10.1111/1467-856X.12027.

- Lehmbruch Gerhard, 2000, Parteienwettbewerb im Bundesstaat. Regelsysteme und Spannungslagen im politischen System der Bundesrepublik Deutschland, Westdeutscher Verlag, Wiesbaden.

- Lorenz Astrid, 2005, 'How to Measure Constitutional Rigidity: Four Concepts and Two Alternatives', Journal of Theoretical Politics, XVII(3): 341-363.

- Lorenz Astrid and Reutter Werner, 2012, 'Subconstitutionalism in a Multilayered System. A Comparative Analysis of Constitutional Politics in the German Länder', Perspectives on Federalism, IV(2): 148170, available at http://www.on-federalism.eu/attachments/141 download.pdf (download: January 10, 2013).

- $\quad$ Lutz Donald S., 1994, 'Toward a Theory of Constitutional Amendment', American Political Science Review, LXXXVIII(2): 355-370.

- $\quad$ Moravcsik Andrew, 1997, Warum die Europäische Union die Exekutive stärkt: Innenpolitik und internationale Kooperation', in Wolf Klaus D. (ed), Projekt Europa im Übergang?, Nomos, Baden-Baden, 211269.

- $\quad$ Putnam, Robert D., 1988, 'Diplomacy and Domestic Politics',International Organization, XLII(3): 427-

460.

- Renzsch Wolfgang, 2000, 'Bundesstaat oder Parteienstaat', in Holtmann Everhard and Voelzkow Helmut (eds), Zwischen Wettbewerbs- und Verhandlungsdemokratie, Westdeutscher Verlag, Wiesbaden, 53-78.

- Roberts Andrew, 2008, 'The Politics of Constitutional Amendment in Postcommunist Europe', Constitutional Political Economy, XX(1): 99-117.

- Robinson James A. and Torvik Ragnar, 2008, Endogenous Presidentialism. Working Paper 14603, available at http://www.nber.org/papers/w14603 (accessed 16 Jan. 2015).

- $\quad$ Scharpf Fritz W., Reissert Bernd and Schnabel Fritz (eds), 1976, Politikverflechtung. Theorie und Empirie des kooperativen Föderalismus in der Bundesrepublik, Scriptor, Königstein/Ts.

- $\quad$ Schmidt Manfred G., 2007, Das politische System Deutschlands, Beck, München.

- Stiens Andrea, 1997, Chancen und Grenzen der Landesverfassungen im deutschen Bundesstaat der Gegenwart, Duncker \& Humblot, Berlin.

- Tarr G. Alan, 1998, Understanding State Constitutions, Princeton University Press, Princeton, N.J.

- $\quad$ Ticchi Davide and Vindigni Andrea, 2010, 'Endogenous Constitutions', Economic Journal, CXX(543):

$1-39$.

- Tsebelis George, 2002, Veto Players: How Political Institutions Work, Princeton University Press, 
Princeton, N.J.

- UNICEF, 2014, Convention on the Rights of the Child, available at: http://www.unicef.org/crc/.

- United Nations, 1990, Convention on the Rights of the Child, available at: http://www.unicef.org/crc/.

- Vermeule Adrian, 2001, 'Veil of Ignorance Rules in Constitutional Law', The Yale Law Journal, CXI(2): 399-433.

- $\quad$ Voigt Stefan, 1997, 'Positive Constitutional Economics: A Survey', Public Choice, XC(1): 11-53.

- Voigt Stefan, 1999, Explaining Constitutional Change. A Positive Economics Approach, Elgar, Cheltenham.

- Weiler Joseph H.H. and Wind Marlene (eds), 2003, European Constitutionalism Beyond the State, Cambridge University Press, Cambridge.

- Wiener, Antje, 2008, The Invisible Constitution of Politics: Contested Norms and International Encounters, Cambridge University Press, Cambridge.

- Wolf Klaus D., 2000, Die neue Staatsräson, Nomos, Baden-Baden.

- Woll Cornelia and Jacquot Sophie, 2010, 'Using Europe: Strategic action in multi-level politics', Comparative European Politics, VIII(1): 110-126. 